\title{
Expression of GAP-43 and SCG10 mRNAs in Lateral Geniculate Nucleus of Normal and Monocularly Deprived Macaque Monkeys
}

\author{
Noriyuki Higo,, ${ }^{1,2}$ Takao Oishi, ${ }^{1}$ Akiko Yamashita, ${ }^{3}$ Keiji Matsuda, ${ }^{1}$ and Motoharu Hayashi ${ }^{4}$ \\ ${ }^{1}$ Neuroscience Section, Information Science Division, Electrotechnical Laboratory, Umezono, Tsukuba, Ibaraki 305-8568, \\ Japan, '2Department of Physiology, University of Tsukuba School of Medicine, Tennodai, Tsukuba, Ibaraki 305-8575, Japan, \\ ${ }^{3}$ Department of Anatomy, Nihon University School of Medicine, Oyaguchi-Kamimachi, Itabashi, Tokyo 173-8610, Japan, \\ and ${ }^{4}$ Department of Cellular and Molecular Biology, Primate Research Institute, Kyoto University, Kanrin, Inuyama, Aichi \\ 484-8506, Japan
}

\begin{abstract}
We performed nonradioactive in situ hybridization histochemistry (ISH) in the lateral geniculate nucleus (LGN) of the macaque monkey to investigate the distribution of mRNA for two growthassociated proteins, GAP-43 and SCG10. GAP-43 and SCG10 mRNAs were coexpressed in most neurons of both magnocellular layers (layers I and II) and parvocellular layers (layers III-VI). Double-labeling using nonradioactive ISH and immunofluorescence revealed that both GAP-43 and SCG10 mRNAs were coexpressed with the $\alpha$-subunit of type II calcium/calmodulindependent protein kinase, indicating that both mRNAs are expressed also in koniocellular neurons in the LGN. We also showed that GABA-immunoreactive neurons in the LGN did not contain GAP-43 and SCG10 mRNAs, indicating that neither GAP-43 nor SCG10 mRNAs were expressed in inhibitory interneurons in the LGN. GABA-immunoreactive neurons in the peri-
\end{abstract}

geniculate nucleus, however, contained both GAP-43 and SCG10 mRNAs, indicating that both mRNAs were expressed in inhibitory neurons in the perigeniculate nucleus, which project to relay neurons in the LGN. Furthermore, to determine whether the expression of GAP-43 and SCG10 mRNAs is regulated by visual input, we performed nonradioactive ISH in the LGN and the primary visual area of monkeys deprived of monocular visual input by intraocular injections of tetrodotoxin. Both mRNAs were downregulated in the LGN after monocular deprivation for $5 \mathrm{~d}$ or longer. From these results, we conclude that both GAP-43 and SCG10 mRNAs are expressed in the excitatory relay neurons of the monkey LGN in an activity-dependent manner.

Key words: GAP-43; SCG10; LGN; macaque monkey; growthassociated protein; koniocellular; GABA; monocular deprivation; in situ hybridization; activity-dependent regulation
During a critical period in the development of the monkey brain, monocular deprivation causes an expansion of geniculocortical axons receiving input from a normal eye and a contraction of geniculocortical axons receiving input from a deprived eye (LeVay et al., 1980). After the critical period, monocular deprivation does not cause such structural rearrangement of geniculocortical axons. Nevertheless, some physiological expansion of ocular dominance columns serving the normal eye of monocularly deprived adult monkeys is also reported, determined by single-unit recording (LeVay et al., 1980).

To investigate the basis for such a plastic response in the adult monkey geniculocortical system, we focused on the expression of two growth-associated proteins, GAP-43 and SCG10, in the lateral geniculate nucleus (LGN) and the primary visual area. GAP-43 is localized in nerve terminals of the neuropil (Nelson and Routtenberg, 1985; Meiri et al., 1986, 1988; Skene et al., 1986) and participates in signal transduction during axonal elongation and synaptic growth (Akers and Routtenberg, 1985; Alexander et al., 1987; Strittmatter et al., 1990). Another growth-associated protein, SCG10, also accumulates in nerve terminals (Stein et al., 1988a) and is thought to participate in axonal elongation and synaptic

Received Nov. 22, 1999; revised June 1, 2000; accepted June 1, 2000.

This work was supported by grants from the Agency of Industrial Science and Technology, the Ministry of International Trade and Industry, Japan, and the Cooperation Research Program of the Primate Research Institute, Kyoto University. We are grateful to Dr. K. Kawano and Dr. T. Arikuni for their valuable discussions and continuous encouragement during this study. We thank Dr. R. L. Neve for providing the cDNA clone for GAP-43 and Dr. N. Mori for providing the cDNA clone for SCG10. We also thank M. Okui, T. Takasu, and A. Kameyama for their excellent technical assistance.

Correspondence should be addressed to Takao Oishi, Neuroscience Section, Information Science Division, Electrotechnical Laboratory, Umezono, Tsukuba, Ibaraki 305-8568, Japan. E-mail: toishi@etl.go.jp.

Copyright (C) 2000 Society for Neuroscience $0270-6474 / 00 / 206030-09 \$ 15.00 / 0$ growth (Stein et al., 1988b; McNeill et al., 1992; Hannan et al., 1996) by regulating the instability of microtubules (Riederer et al., 1997). GAP-43 and SCG10 are abundant in a developing nervous system and persist in certain regions of the adult nervous system such as the association areas of the cerebral cortex and the hippocampus, where structural or functional changes may continue to occur (Neve et al., 1988; Benowitz et al., 1989; Himi et al., 1994a,b; Sugiura and Mori, 1995; Higo et al., 1998, 1999a; Oishi et al., 1998). It is generally believed that these growth-associated proteins serve as an intrinsic determinant of synaptic growth and plasticity even in the adult brain (McNeill et al., 1992; Aigner et al., 1995; Holtmaat et al., 1995; Kapfhammer, 1997) (for review, see Benowitz and Routtenberg, 1997).

To understand the synaptic plasticity in the geniculocortical system by using GAP-43 and SCG10 as molecular markers, the first step is to determine the localization of GAP-43 and SCG10 mRNAs. Recently, we performed a nonradioactive in situ hybridization histochemistry (ISH) in the primary visual area and revealed that prominent hybridization signals for GAP-43 and SCG10 mRNAs are restricted to layers IV-VI (Higo et al., 1999a). In this study, we applied the same method to the monkey LGN, which includes three types of excitatory relay neurons (magnocellular, parvocellular, and koniocellular neurons), plus inhibitory interneurons (Hendry and Calkins, 1998).

The second step is to determine whether the expression of GAP-43 and SCG10 mRNAs in the geniculocortical system is regulated by the visual input. Thus, we performed a nonradioactive ISH in both the LGN and the primary visual area of monkeys deprived of monocular visual input by intraocular injections of tetrodotoxin (TTX). We found that both mRNAs were downregulated in the LGN but not in the primary visual area of monocularly deprived monkeys.

Preliminary results have been published previously (Higo et al., 1999b,c). 


\section{MATERIALS AND METHODS}

Animals and tissue preparation. Brain tissue was obtained from 11 macaque monkeys (six Macaca fuscata and five Macaca mulatta) aged 2 or more years. Monkeys were purchased from a local provider or were bred in the Primate Research Institute, Kyoto University. To investigate the effect of visual deprivation on the expression of GAP-43 and SCG10 mRNAs, five monkeys received TTX (Sigma, St. Louis MO) $(15 \mu \mathrm{g}$ in $10 \mu \mathrm{l}$ of norma saline), injected intravitreously into the right eye every fifth day for a total of $5(n=2), 10(n=2)$, and $30(n=1) \mathrm{d}$ before they were killed. Monkeys were anesthetized with ketamine hydrochloride $(10 \mathrm{mg} / \mathrm{kg}$, i.m.) and pentobarbital sodium (Nembutal; $20 \mathrm{mg} / \mathrm{kg}$, i.v.) before TTX administration. The pupillary light reflex of these monocularly deprived monkeys remained suppressed throughout the deprivation period.

All animals were pretreated with ketamine hydrochloride $(10 \mathrm{mg} / \mathrm{kg}$, i.m.), then deeply anesthetized with Nembutal (35 mg/kg, i.v.). Next, they were perfused through the ascending aorta with 0.51 of ice-cold saline containing $2 \mathrm{ml}(2000 \mathrm{U})$ of heparin sodium, followed by $2-51$ of ice-cold fixative: $4 \%$ paraformaldehyde (PFA) and $0.1 \%$ glutaraldehyde in $0.15 \mathrm{M}$ phosphate buffer (PB), pH 7.4. During perfusion, the monkeys' heads were chilled with crushed ice. After perfusion, the brains were immediately removed and blocked in the coronal plane ( $5 \mathrm{~mm}$ thick). The occipital lobe was blocked in a plane parallel to the cortex. They were then immersed in a postfixative solution containing $2 \%$ PFA and $5 \%$ sucrose in $0.15 \mathrm{M}$ PB for several hours, followed by successive immersions in 10,20 , and $30 \%$ sucrose in $0.15 \mathrm{M}$ PB. The brain blocks were mounted in O.C.T. compound (Miles Inc., Elkhart, IN) and frozen rapidly in a dry ice/acetone bath, then stored at $-80^{\circ} \mathrm{C}$ until dissection.

In situ hybridization. Digoxigenin-labeled RNA probes were used for the detection of GAP-43 and SCG10 mRNAs. RNA probes for GAP-43 and SCG10 were transcribed from human cDNA clones for GAP-43 (pG\#20, 500 bp; a gift from Dr. R. L. Neve, Harvard Medical School, Boston) and SCG10 (pSG601, 550 bp; a gift from Dr. N. Mori, National Institute for Longevity Sciences, Oobu, Aichi, Japan), using an in vitro transcription method according to the manufacturer's instructions (DIG-RNA Labeling Kit, Boehringer Mannheim Biochemica, Mannheim, Germany). Before use, the labeled probes were precipitated with ethanol, then washed to remove unincorporated digoxigenin-labeled nucleotides.

Tissue blocks containing the LGN or the primary visual cortex were sliced into 16- $\mu \mathrm{m}$-sections on a cryostat (CRYOCUT 3000, Leica, Nussloch, Germany). The sections were mounted on slides coated with Vectabond Reagent (Vector Laboratories, Burlingame CA), dried, then pretreated for ISH by successive incubations in $4 \%$ PFA in $0.1 \mathrm{M} \mathrm{PB}$ for $15 \mathrm{~min}$ at room temperature, $30 \mu \mathrm{g} / \mathrm{ml}$ Proteinase $\mathrm{K}$ (Boehringer Mannheim Biochemica), $\mathrm{pH} 8.0$, for $30 \mathrm{~min}$ at $37^{\circ} \mathrm{C}$, and $4 \% \mathrm{PFA}$ in $0.1 \mathrm{M} \mathrm{PB}$ for 10 min at room temperature. After washing with $0.1 \mathrm{M} \mathrm{PB}$, the sections were dehydrated through $70,80,90$, and $100 \%$ ethanol serial washes (1 min at each concentration) and then dried.

Sections were prehybridized in $50 \%$ formamide, $600 \mathrm{~mm} \mathrm{NaCl}, 1 \times$ Denhardt's solution, $0.25 \%$ SDS, 10 mM Tris-HCl, pH 7.6, 1 mm EDTA, and $200 \mu \mathrm{g} / \mathrm{ml}$ tRNA for $3 \mathrm{hr}$ at $50^{\circ} \mathrm{C}$. After prehybridization, sections were transferred to fresh hybridization buffer containing an additiona $10 \%$ dextran sulfate and $1 \mu \mathrm{g} / \mathrm{ml}$ digoxigenin-labeled RNA probe. Hybridization continued for at least $16 \mathrm{hr}$ at $50^{\circ} \mathrm{C}$. The hybridized sections were rinsed three times in $5 \times \mathrm{SSC}$ at room temperature, then washed three times $\left(10 \mathrm{~min}\right.$ each) in preheated $2 \times \mathrm{SSC}, 50 \%$ formamide at $48^{\circ} \mathrm{C}$. Next, sections were treated with $10 \mathrm{~mm}$ Tris- $\mathrm{HCl}, \mathrm{pH} 7.5,1 \mathrm{~mm}$ EDTA, $0.5 \mathrm{M}$ $\mathrm{NaCl}$ containing RNase A (Boehringer Mannheim Biochemica; $30 \mu \mathrm{g} / \mathrm{ml}$ ) for $30 \mathrm{~min}$ at $37^{\circ} \mathrm{C}$, then washed in $2 \times \mathrm{SSC}$ for $20 \mathrm{~min}$ at $50^{\circ} \mathrm{C}$ and twice in $0.2 \times \mathrm{SSC}$ at $50^{\circ} \mathrm{C}$, for $20 \mathrm{~min}$ each time.

The buffer was changed to $0.1 \mathrm{M}$ maleic acid, $0.15 \mathrm{M} \mathrm{NaCl}$, and $0.2 \%$ Tween 20 , pH 7.5, with a $10 \mathrm{~min}$ wash at room temperature. Sections were then incubated in $2 \%$ blocking reagent (DIG Nucleic Acid Detection Kit Boehringer Mannheim Biochemica), $0.1 \mathrm{M}$ maleic acid, and $0.15 \mathrm{M} \mathrm{NaCl}$, $\mathrm{pH} 7.5$, for $1 \mathrm{hr}$ at room temperature, then incubated in 1:500 diluted anti-digoxigenin Fab-fragments conjugated with alkaline phosphatase (DIG Nucleic Acid Detection Kit, Boehringer Mannheim Biochemica) in $2 \%$ blocking reagent, $0.1 \mathrm{M}$ maleic acid, and $0.15 \mathrm{M} \mathrm{NaCl}, \mathrm{pH} 7.5$, for $3 \mathrm{hr}$ at room temperature. Unbound antibody conjugate was removed by washing three times for $10 \mathrm{~min}$ each with $0.1 \mathrm{M}$ maleic acid, $0.15 \mathrm{M} \mathrm{NaCl}$, and $0.2 \%$ Tween 20, pH 7.5. Finally, the sections were preincubated in $0.1 \mathrm{M}$ Tris- $\mathrm{HCl}$ buffer, $\mathrm{pH} 9.5$, containing $0.1 \mathrm{M} \mathrm{NaCl}$ and $0.05 \mathrm{M} \mathrm{MgCl}_{2}$ for 5 min, then incubated for $20 \mathrm{hr}$ in the dark in the same buffer containing the substrates: nitroblue tetrazolium (NBT) $(340 \mu \mathrm{g} / \mathrm{ml}$; Boehringer Mannheim Biochemica) and 5-bromo-4-chloro-3 indolyl phosphate (BCIP, 170 $\mu \mathrm{g} / \mathrm{ml}$ ) (Boehringer Mannheim Biochemica). Color development was stopped by incubation in $0.1 \mathrm{M}$ Tris- $\mathrm{HCl}$ buffer, $\mathrm{pH} 7.5$, containing $0.01 \mathrm{M}$ EDTA for $10 \mathrm{~min}$. The sections were incubated in $4 \%$ PFA in $0.15 \mathrm{M} \mathrm{PB}$ for $10 \mathrm{~min}$ at room temperature to prevent fading. After this, sections were dehydrated through $70,80,90$, and $100 \%$ ethanol serial washes $(1 \mathrm{~min}$ at each concentration), transferred to xylene for three washes of 5 min each, then covered with coverslips and Permount histological mounting medium (Fisher Scientific, Fair Lawn, NJ).

The specificity of the probes was confirmed by Northern blot analysis, in which specific bands for both GAP-43 and SCG10 mRNAs were observed as in a previous study (Higo et al., 1998). In addition, control sections were hybridized using the same method described above, using the sense probes for both mRNAs. These control sections showed no specific signals (see Fig. $1 D, E)$.

Double-label ISH. To investigate whether GAP-43 and SCG10 mRNAs are coexpressed in the single neuron of the LGN, double-label ISH was performed. For this purpose, we synthesized a digoxigenin-labeled probe for GAP-43 mRNA and a biotin-labeled probe for SCG10 mRNA. To amplify the signals from the biotin-labeled probes, we used the tyramide signal amplification technique (TSA-indirect, NEN Life Science Products, Boston, MA).

The biotin-labeled probe was made using an in vitro transcription method according to the manufacturer's instructions (DIG-RNA Labeling Kit and Biotin RNA Labeling Mix, Boehringer Mannheim Biochemica). Before use, the labeled probes were precipitated with ethanol, then washed to remove unincorporated biotin-labeled nucleotides. The pretreatment, prehybridization, hybridization, and washing of the probes were performed in the same manner as described above, except the hybridization took place in the buffer containing both the digoxigenin-labeled probes for GAP-43 mRNA and the biotin-labeled probes for SCG10 mRNA. After the probes were washed, the buffer was changed to $0.1 \mathrm{M}$ Tris- $\mathrm{HCl}, 0.15 \mathrm{M} \mathrm{NaCl}$, and $0.05 \%$ Tween 20, $\mathrm{pH} 7.5$, and the probes were incubated for $15 \mathrm{~min}$ at room temperature. Tissue sections were incubated in $0.5 \%$ blocking reagent (TSA-indirect, NEN Life Science Products), $0.1 \mathrm{M}$ Tris- $\mathrm{HCl}$, and $0.15 \mathrm{M}$ $\mathrm{NaCl}, \mathrm{pH} 7.5$, for $1 \mathrm{hr}$ at room temperature, then were incubated in 1:100 diluted streptavidin-HRP (TSA-indirect, NEN Life Science Products),

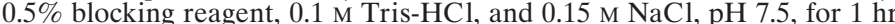
at room temperature. Unbound streptavidin-HRP was removed by washing three times for 5 min each with $0.1 \mathrm{M}$ Tris- $\mathrm{HCl}, 0.15 \mathrm{M} \mathrm{NaCl}$, and $0.05 \%$ Tween 20, pH 7.5. Sections were incubated in Biotinyl Tyramide Working Solution (TSA-indirect, NEN Life Science Products) for $20 \mathrm{~min}$, then washed three times for 5 min each with $0.1 \mathrm{M}$ Tris- $\mathrm{HCl}, 0.15 \mathrm{M} \mathrm{NaCl}$, and $0.05 \%$ Tween 20 , pH 7.5. Sections were then incubated in 1:100 diluted Streptavidin-Alexa488 (Molecular Probes, Eugene OR), 0.5\% blocking reagent, $0.1 \mathrm{M}$ Tris- $\mathrm{HCl}$, and $0.15 \mathrm{M} \mathrm{NaCl}$, $\mathrm{pH} 7.5$, for $30 \mathrm{~min}$ at $48^{\circ} \mathrm{C}$. After washing three times for $10 \mathrm{~min}$ each with $0.1 \mathrm{M}$ Tris- $\mathrm{HCl}, 0.15 \mathrm{M} \mathrm{NaCl}$, and $0.05 \%$ Tween $20, \mathrm{pH} 7.5$, the sections were covered with coverslips and a $0.1 \mathrm{M} \mathrm{PBS} /$ glycerol solution. Images were captured with a fluorescence microscope (BX60; Olympus, Tokyo, Japan) equipped with an illuminator (BX-FLA; Olympus), using a 3CCD color video camera (DXC-950; Sony, Tokyo, Japan). Next, the sections were incubated in $0.1 \mathrm{M}$ maleic acid, 0.15 $\mathrm{M} \mathrm{NaCl}$, and $0.2 \%$ Tween $20, \mathrm{pH} 7.5$, to remove the coverslips, and digoxigenin-labeled probes for GAP-43 were visualized with NBT and BCIP by the same methods described above.

To evaluate the specificities of the biotin-labeled probes for SCG10 mRNA, control sections were hybridized using the same method described above, using the sense probe. These control sections showed no specific signals (data not shown).

Double-labeling using ISH and immunofluorescence. To investigate whether GAP-43 and SCG10 mRNAs are coexpressed with the $\alpha$-subunit of type II calcium/calmodulin-dependent protein kinase (CAMKII- $\alpha$ ) or GABA in the LGN of normal monkeys, we conducted double-labeling experiments using nonradioactive ISH and immunofluorescence. We performed immunofluorescence first, capturing the immunofluorescent image, and then performed nonradioactive ISH.

The sections were rinsed three times in $0.1 \mathrm{M} \mathrm{PBS}, \mathrm{pH} \mathrm{7.4,} \mathrm{and} \mathrm{prein-}$ cubated in $1 \%$ BSA, $0.02 \%$ sodium azide, and $0.6 \%$ Triton X-100 in PBS for $4 \mathrm{hr}$ at room temperature. Sections were then incubated for $60 \mathrm{hr}$ at $4^{\circ} \mathrm{C}$ in the primary antibodies, a mouse monoclonal antibody to CAMKII- $\alpha$ (6G9; Biomol Research Laboratories, Plymouth Meeting, PA) diluted $1: 100$ in $0.1 \mathrm{M}$ PBS containing $1 \% \mathrm{BSA}, 0.02 \%$ sodium azide, and $0.3 \%$ Triton X-100, or a mouse monoclonal antibody to GABA (GB69; Sigma) diluted 1:800 in the same buffer. After washing three times for 15 min each with $0.1 \mathrm{M}$ PBS, the sections were incubated for $12 \mathrm{hr}$ at room temperature in the secondary antibody, Alexa 488 goat anti-mouse IgG $(\mathrm{H}+\mathrm{L})$ conjugate (Molecular Probes) diluted 1:400 in 0.1 M PBS containing 1\% BSA, $0.02 \%$ sodium azide, and $0.3 \%$ Triton X-100. After washing three times for $15 \mathrm{~min}$ each with $0.1 \mathrm{M}$ PBS, the sections were covered with coverslips and a $0.1 \mathrm{M} \mathrm{PBS} /$ glycerol solution. Images were captured with a fluorescence microscope (BX60; Olympus) equipped with an illuminator (BX-FLA; Olympus), using a 3CCD color video camera (DXC-950; Sony). The sections were incubated in $0.1 \mathrm{M} \mathrm{PBS}$ to remove the coverslips, then were hybridized with the digoxigenin-labeled probes of GAP-43 or SCG10, as described above.

The specificity of each primary antibody was confirmed in previous studies (Kalyuzhny and Wessendorf, 1998; Tanigawa et al., 1998; Tighilet et al., 1998a,b). Control sections were processed using the same method described above, except the primary antibodies were excluded. These control sections showed no specific signals (data not shown).

Quantification. To quantify the expression patterns in the LGN and the primary visual area of monocularly deprived monkeys, images of in situ hybridized sections or adjacent Nissl- or cytochrome oxidase-stained sections were captured with an Olympus BX60 microscope using a 3CCD color video camera (DXC-950; Sony). The images were then digitized with an image analysis system (MCID; Imaging Research Inc., St. Catharines, Canada)

In the LGN, optical density was measured in each layer of a $300-\mu \mathrm{m}$ wide column that sampled from layer I to layer VI, and the optical density of the background staining was measured in the neighboring cell-free 
regions. $\mathrm{OD}(\%$ Background $)$ was defined as a percentage of optical density to that of the background staining (see Figs. $4 C, D, G, H, 5 C, D, G, H$ ). The layers of in situ hybridized sections were identified by adjacent Nisslstained sections.

In the primary visual area, we showed the relative optical density in each section in pseudocolor representation. The resolutions of the digitized images were reduced from $1.03 \times 10^{2} \mathrm{~mm}^{2} / 4096 \times 4096$ pixels to $2.52 \times$ $10^{3} \mathrm{~mm}^{2} / 4096 \times 4096$ pixels, and the optical density was measured in each pixel. Using MATLAB version 5.0.0 (The Math Works Inc., Natick, MA) on a Power Macintosh G3 (Apple Computer, Inc., Cupertino, CA), the optical density in each pixel was plotted in pseudocolor representation (see Fig. $8 B, D, F, H)$.

\section{RESULTS}

\section{Expression of GAP-43 and SCG10 mRNAs in normal LGN}

In normal LGN, expression of both GAP-43 and SCG10 mRNAs was observed in the neurons of all layers (Fig. $1 B, C$ ). The hybridization signals for SCG10 mRNA were more intense than those for GAP-43 mRNA. Weak signals for GAP-43 mRNA and intense signals for SCG10 mRNA were also observed in the perigeniculate nucleus (Fig. $1 B, C$ ). These results were similar among all animals examined $(n=6)$ and throughout the rostral to caudal levels of the coronal sections. Higher-magnification photomicrographs revealed that many GAP-43 mRNA- or SCG10 mRNA-positive neurons existed in magnocellular layers (layers I and II), in parvocellular layers (layers III-VI), and in interlaminar regions (Fig. 1G,H). These neurons varied in size $(10-30 \mu \mathrm{m}$ in diameter), and were oval, triangular, or rectangular in shape. Double-label ISH study revealed that GAP-43 and SCG10 mRNAs colocalized in most LGN neurons (Fig. 2). Signals were selective for GAP-43 mRNA (Fig. 2A,C, arrows) or SCG10 mRNA (Fig. 2B,C, arrowheads) in some LGN neurons.

Recent studies revealed that there is a third population of neurons in the primate LGN, in addition to the magnocellular and parvocellular neurons, known as koniocellular neurons. A subset of koniocellular neurons relay excitatory input from shortwavelength-sensitive cones in the retina (Martin et al., 1997; Reid et al., 1997; for review, see Komatsu, 1998) and send retinal signals directly to the blobs of the primary visual area of the cerebral cortex (Hendry and Yoshioka, 1994; Hendry and Calkins, 1998). To investigate whether GAP-43 and SCG10 mRNAs are expressed in koniocellular neurons as well as in magnocellular and parvocellular neurons, we used a double-labeling technique involving nonradioactive ISH of GAP-43 and SCG10 mRNA and immunofluorescence of CAMKII- $\alpha$, a molecular marker of koniocellular neurons (Hendry and Yoshioka, 1994; Hendry and Calkins, 1998). Most CAMKII- $\alpha$-immunoreactive neurons were observed in regions ventral to each of six layers as reported previously (Hendry and Yoshioka, 1994; Hendry and Calkins, 1998) and were relatively small in size $(10-20 \mu \mathrm{m}$ in diameter) and round in shape (Fig. 3B,E). Our double-labeling experiments confirmed that nearly all CAMKII- $\alpha$-positive neurons expressed mRNAs of GAP-43 and SCG10 (Fig. $3 A-F$ ), indicating that koniocellular neurons as well as magnocellular and parvocellular neurons contain GAP-43 and SCG10 mRNAs.

We also conducted double-labeling experiments involving nonradioactive ISH of GAP-43 and SCG10 mRNA and immunofluorescence of GABA. In the LGN, GABA-immunoreactive neurons were observed in both magnocellular and parvocellular layers and varied in size $(10-30 \mu \mathrm{m}$ in diameter) and shape (Fig. $3 H, K)$, as reported previously (Montero and Zempel, 1986). The doublelabeling experiments confirmed that GAP-43 and SCG10 mRNAs were not expressed in GABA-immunoreactive neurons (Fig. 3G$L)$. Previous studies confirmed that GABA is expressed in inhibitory interneurons in the LGN (Fitzpatrick et al., 1984; Montero and Zempel, 1985; Montero and Zempel, 1986). Thus, the results of the present study indicate that GAP-43 and SCG10 mRNAs are not expressed in inhibitory interneurons. Some of the GAP-43 or SCG10 mRNA-positive neurons were outlined by GABAimmunoreactive terminals (Fig. 3G-L, arrows).

In the perigeniculate nucleus, nearly all neurons were GABA- ergic (Fig. 3N,Q), consistent with previous studies (Hendrickson et al., 1983; Hendry, 1991), and most of them were fusiform in shape (20-50 $\mu \mathrm{m}$ in length). GABAergic neurons in the perigeniculate nucleus contained both GAP-43 and SCG10 mRNAs (Fig. $3 M-R$ ).

\section{Effect of monocular deprivation}

Figure 4 shows the effects of monocular deprivation in the LGN ipsilateral to the TTX-injected eye. The level of staining for cytochrome oxidase was lower in layers II, III, and V than layers I, IV, and VI (Fig. 4B,D). This indicates that neuronal activity was reduced in these layers, as the result of visual deprivation of the ipsilateral eye. The amount of both GAP-43 and SCG10 mRNAs was also lower in layers II, III, and V than in layers I, IV, and VI (Fig. $4 E-H$ ), indicating that both GAP-43 and SCG10 mRNAs were downregulated in the layers deprived of visual input. In the adjacent Nissl-stained section, however, the apparent reduction of staining was not observed (Fig. 4A,C), indicating that cell shrinkage did not occur in the deprived layers. In the LGN contralateral to the TTX-injected eye, just the opposite was observed. The levels of staining for cytochrome oxidase and of GAP-43 and SCG10 mRNAs were lower in layers I, IV, and VI than layers II, III, and $\mathrm{V}$, although the apparent reduction of staining was not observed in the Nissl-stained section (Fig. 5). These results further confirmed that layers deprived of visual activity display lower levels of hybridization signals for both GAP-43 and SCG10 mRNAs than those of normally active layers. In the deprived layers, the hybridization signals for both GAP-43 and SCG10 mRNAs were reduced in nearly all neurons (Fig. 6). The signals were downregulated in all monocularly deprived monkeys regardless of the length of the deprivation period: $5 \mathrm{~d}(n=2), 10 \mathrm{~d}(n=2)$, or $30 \mathrm{~d}(n=1)$ (Fig. $7)$. These results were similar throughout the rostral to caudal levels of the coronal sections. In the perigeniculate nucleus, the expression of both GAP-43 and SCG10 mRNAs was retained even after monocular deprivation for each period.

After monocular deprivation for 5, 10, or $30 \mathrm{~d}$, we observed a periodic pattern of staining for cytochrome oxidase, especially in layer IVC of the primary visual area of the cerebral cortex (Fig. $8 C, D$ ), indicating that neuronal activity of ocular dominance columns that received visual input from the TTX-injected eye was reduced. However, we did not detect such a periodic ocular dominance pattern of staining for GAP-43 and SCG10 mRNAs after monocular deprivation for each period (Fig. $8 E-H$ ). Slight unequal distributions of both GAP-43 and SCG10 mRNAs in layer IVC correlated with the cell density revealed by the Nissl-stained section (Fig. $8 A, B$ ). The hybridization patterns for both GAP-43 and SCG10 mRNAs were nearly identical to those we had previously reported for normal monkeys (Higo et al., 1999a). These results indicate that in the primary visual area, the expression of GAP-43 and SCG10 mRNAs is not affected after monocular deprivation for these periods.

\section{DISCUSSION}

\section{Expression of GAP-43 and SCG10 in the visual system of monkey}

The present study showed that mRNAs of GAP-43 and SCG10, presynaptic determinants of synaptic growth and plasticity, were expressed in most neurons of the magnocellular, parvocellular, and koniocellular layers in the LGN. The expression of GAP-43 and SCG10 proteins is likely to be regulated by mRNA stability (Federoff et al., 1988; Perrone-Bizzozero et al., 1993; Nishizawa, 1994; Hannan et al., 1996), and several in vivo studies confirmed that the expression of GAP-43 and SCG10 mRNAs in the neuronal cell body is correlated with the expression of GAP-43 and SCG10 proteins in the axon terminals (Van der Zee et al., 1989; Tetzlaff et al., 1991; Linda et al., 1992; Chong et al., 1994; Bendotti et al., 1997; McNeill et al., 1999). Neurons in the koniocellular layer project to both the blobs of the primary visual area (Hendry and Yoshioka, 1994; Hendry and Calkins, 1998) and the prestriate area (Benevento and Yoshida, 1981; Fries, 1981; Yukie and Iwai, 1981; Bullier and Kennedy, 1983; Lysakowski et al., 1988), indicating that 

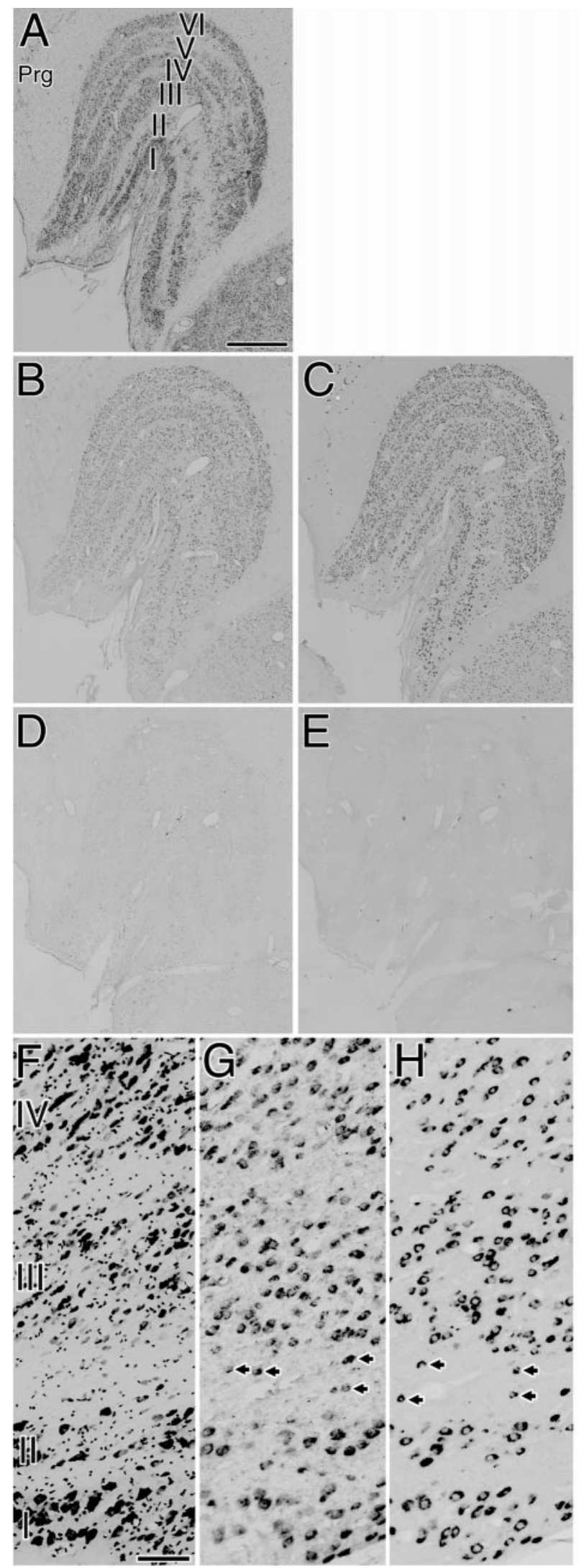

Figure 1. $A-E$, Five adjacent sections of the normal LGN. Expression of both GAP-43 and SCG10 mRNAs was observed in the neurons of all layers. The expression patterns of both GAP-43 and SCG10 mRNAs were similar among all animals examined and throughout the rostral to caudal levels of the coronal sections. $A$, Nissl-stained section. $B$, Localization of GAP-43 mRNA. $C$, Localization of SCG10 mRNA. $D$, Control section hybridized with a sense probe for GAP-43. E, Control section hybridized with a sense probe for SCG10. Prg, Perigeniculate nucleus. Scale bar, $1 \mathrm{~mm}$. $F-H$,

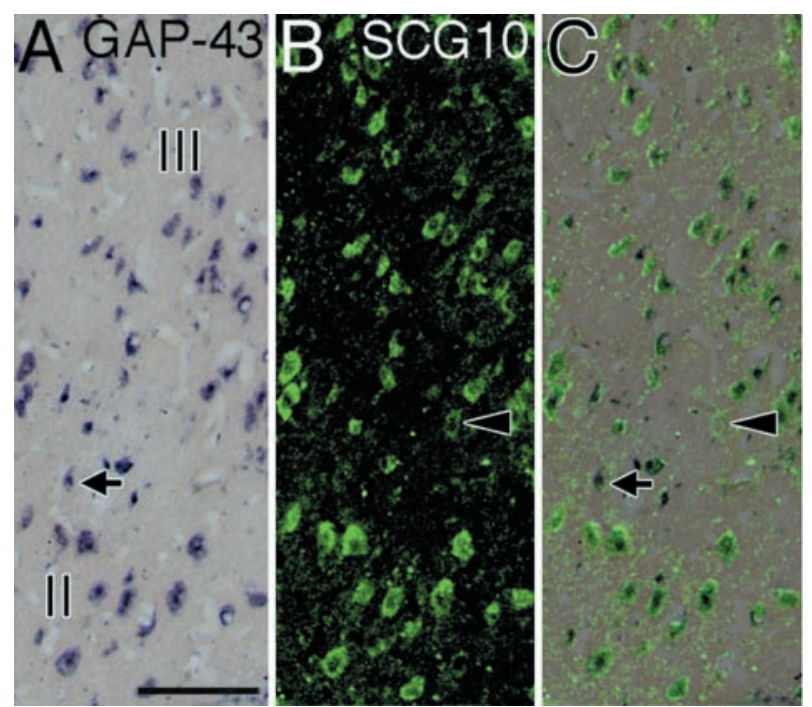

Figure 2. Coexpression of GAP-43 and SCG10 mRNAs in layers II and III of the LGN. $A$, Localization of GAP-43 mRNA. $B$, Localization of SCG10 mRNA in the same section as $A$. $C$, The image of $B$ was superimposed on the image of $A$. Most of the neurons contained the hybridization signals for both GAP-43 mRNA (dark blue) and SCG10 mRNA (green). In some neurons, the signal was selective for GAP-43 mRNA (arrows) or SCG10 mRNA (arrowheads). Scale bar, $100 \mu \mathrm{m}$.

GAP-43 and SCG10 exist in the axon terminals of these projections. Neither the GAP-43 nor SCG10 mRNA-positive neurons in both magnocellular and parvocellular layers contained GABA, indicating that GAP-43 and SCG10 mRNAs were expressed in most of the excitatory relay neurons in these layers. Excitatory relay neurons in the magnocellular and parvocellular layers of the LGN project to layers IVC $\alpha$ and IVC $\beta$ of the primary visual area, respectively (Wilson and Cragg, 1967; Garey and Powell, 1971; Hubel and Wiesel, 1972; Hendrickson et al., 1978). Thus GAP-43 and SCG10 should exist in the geniculocortical axon terminals in the primary visual area. The result is consistent with the previous study showing that GAP-43 protein is localized in the neuropil around neurons in layer IV of the cat primary visual area (Liu et al., 1996). In the LGN, the expression of both GAP-43 and SCG10 mRNAs was downregulated after monocular deprivation for $5 \mathrm{~d}$ or longer. Because in vivo studies confirmed that the downregulation of GAP-43 and SCG10 mRNAs is followed by the downregulation of GAP-43 and SCG10 proteins (Van der Zee et al., 1989; McNeill et al., 1999), the downregulation of GAP-43 and SCG10 mRNA in relay neurons of the LGN should result in the downregulation of GAP-43 and SCG10 proteins in the geniculocortical axon terminals.

In the primary visual area of both normal and monocularly deprived monkeys, prominent hybridization signals for both GAP-43 and SCG10 mRNAs were observed in layers IV-VI (Higo et al., 1999a; present study). Intense signals were frequently observed in Meynert cells in layers IVB, V, and VI, which project to area MT of the cortex or the superior colliculus (Lund and Boothe, 1975; Tigges et al., 1981; Fries and Distel, 1983; Sipp and Zeki, 1989; Peters, 1994). In contrast to the result in the LGN, the expression of GAP-43 and SCG10 mRNAs in the primary visual area was not affected by monocular deprivation. The lack of effect on the expression of GAP-43 mRNA in the primary visual area is consistent with the previous study showing that dark rearing after

Higher-magnification photomicrographs. $F$, Nissl-stained sections. $G$, Localization of GAP-43 mRNA. $H$. Localization of SCG10 mRNA. Arrows indicate GAP-43 or SCG10 mRNA-positive neurons in the interlaminar regions. Many GAP-43 or SCG10 mRNA-positive neurons existed in magnocellular layers (layers I and II), parvocellular layers (layers III-VI), and interlaminar regions. Scale bar, $100 \mu \mathrm{m}$. 


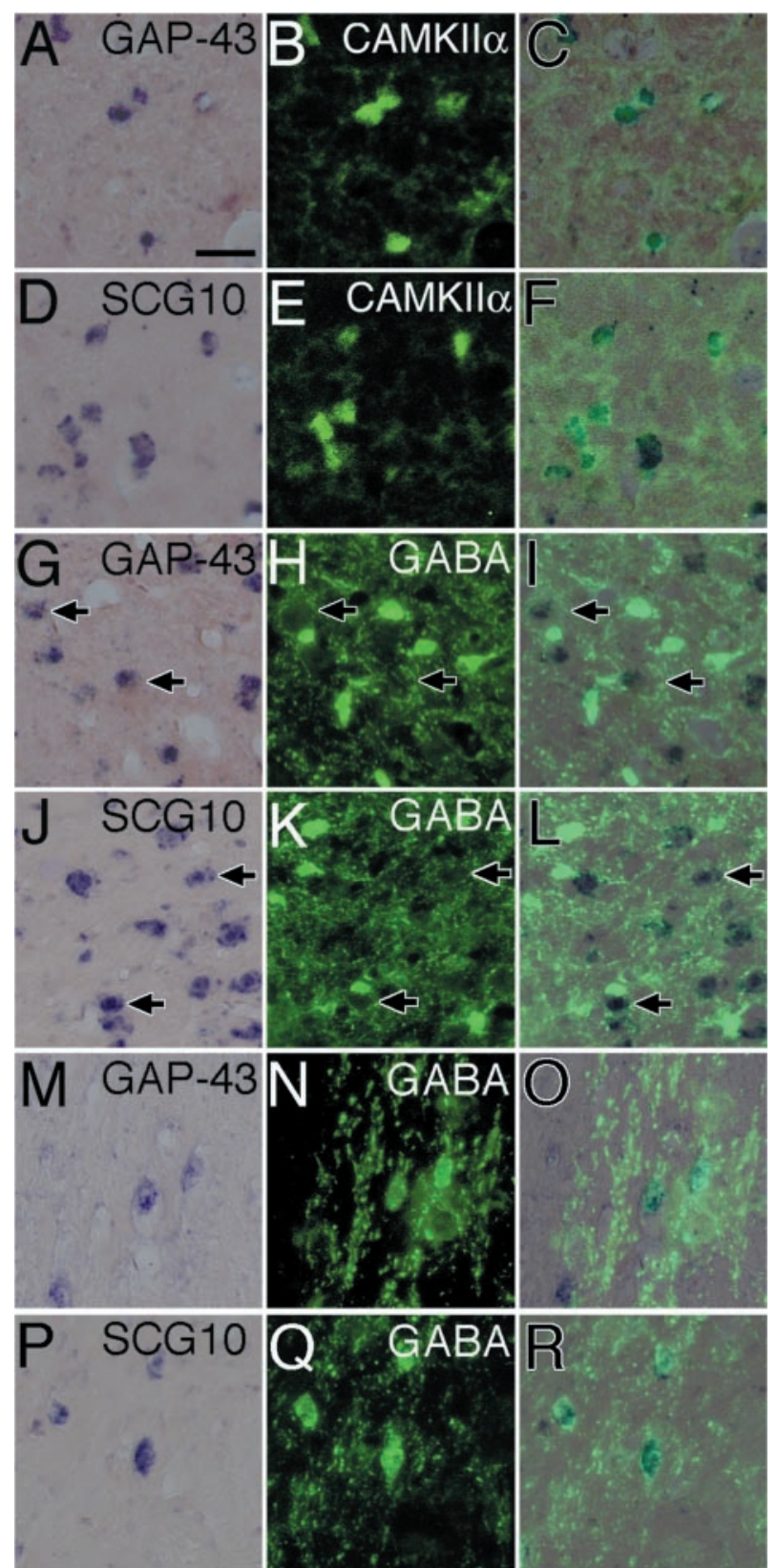

Figure 3. $A-F$, Expression of GAP-43 and SCG10 mRNAs in CAMKII$\alpha$-immunoreactive neurons (koniocellular neurons) in the interlaminar region between layers I and II of the LGN. $A$, Localization of GAP-43 mRNA. $B$, Localization of CAMKII- $\alpha$ in the same section as $A . C$, The image of $B$ was superimposed on the image of $A$. CAMKII- $\alpha$ immunoreactive neurons (green) expressed GAP-43 mRNA (dark blue). $D$, Localization of SCG10 mRNA. E, Localization of CAMKII- $\alpha$ in the same section as $D$. F , The image of $E$ was superimposed on the image of $D$. CAMKII- $\alpha$-immunoreactive neurons (green) expressed SCG10 mRNA (dark blue). $G-L$, Absence of GAP-43 and SCG10 mRNAs in GABAimmunoreactive neurons in layer II of the LGN. Arrows indicate GAP-43 or SCG10 mRNA-positive neurons that were outlined by GABAimmunoreactive terminals. $G$, Localization of GAP-43 mRNA. $H$, Localization of GABA in the same section as $G$. I, The image of $H$ was superimposed on the image of $G$. GABA-immunoreactive neurons (green) did not express GAP-43 mRNA (dark blue). $J$, Localization of SCG10 mRNA. $K$, Localization of GABA in the same section as $J$. $L$, The image of $K$ was superimposed on the image of $J$. GABA-immunoreactive neurons (green) did not express SCG10 mRNA (dark blue). $M-R$, Expression of GAP-43 and SCG10 mRNAs in GABA-immunoreactive neurons in the perigeniculate nucleus. $M$, Localization of GAP-43 mRNA. $N$, Localization of GABA in the same section as $M$. $O$, The image of $N$ was superimposed on the image of $M$. GABA-immunoreactive neurons (green) expressed GAP-43 mRNA (dark blue). P, Localization of SCG10 mRNA. $Q$, Localization of GABA in the same section as $P$. $R$, The image of $Q$ was superimposed on the image of $P$. GABA-immunoreactive neurons (green) expressed SCG10 mRNA (dark blue). Scale bar, $50 \mu \mathrm{m}$.
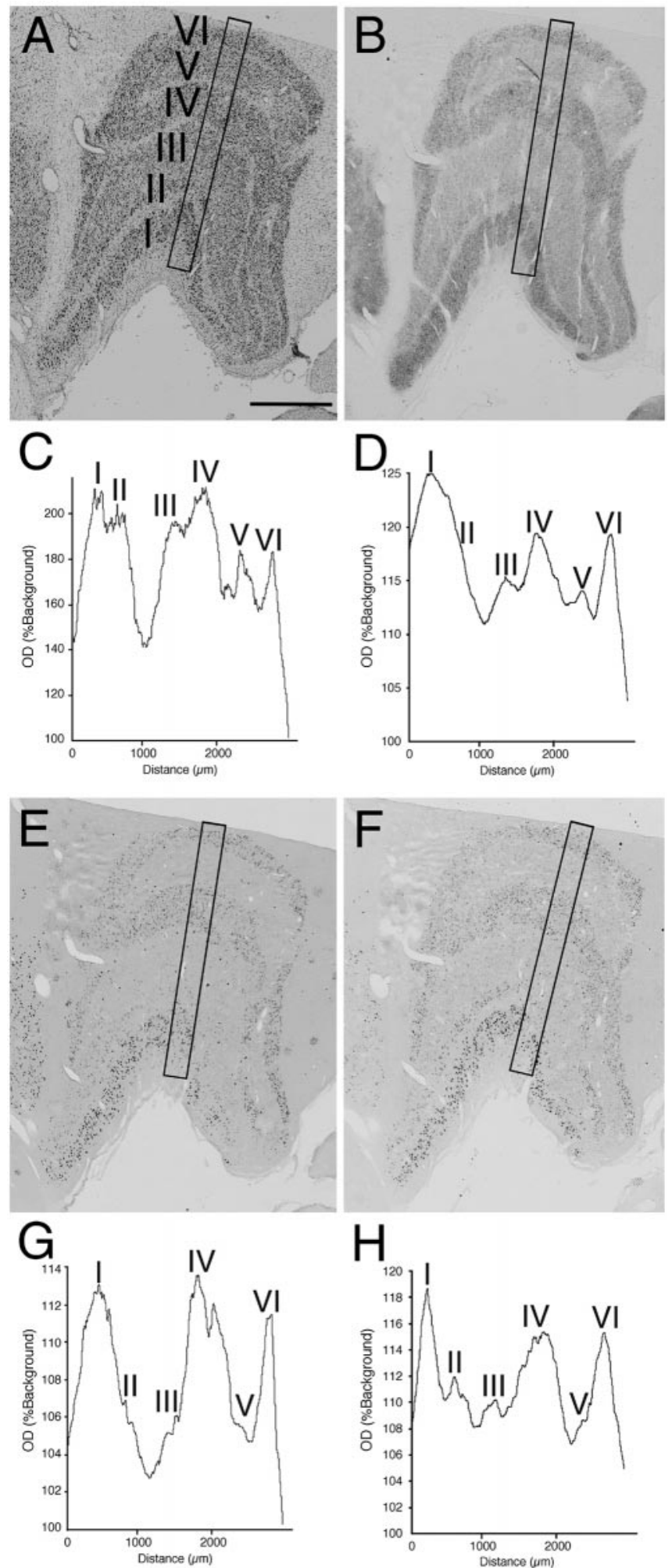

Figure 4. The effects of monocular deprivation in the LGN ipsilateral to the TTX-injected eye. This figure shows the results of a monkey that has been monocularly deprived for $10 \mathrm{~d}$. The hybridization signals for both GAP-43 and SCG10 mRNAs were lower in layers innervated by the TTX-injected eye (layers II, III, and V) than in layers innervated by a normal eye (layers I, IV, and VI). $A$, Nissl-stained section. $B$, Cytochrome oxidase-stained section. $C, O D(\%$ Background $)$ from a $300-\mu$ m-wide column sampling all layers of Nissl-stained LGN $(A)$. $D, O D(\%$ Background) from cytochrome oxidase-stained LGN $(B)$. $E$, Localization of GAP-43 mRNA. $F$, Localization of SCG10 mRNA. $G, O D(\%$ Background) from the LGN hybridized for GAP-43 mRNA $(E)$. H, OD(\%Background) from the LGN hybridized for SCG10 mRNA $(F)$. Scale bar, $1 \mathrm{~mm}$. 

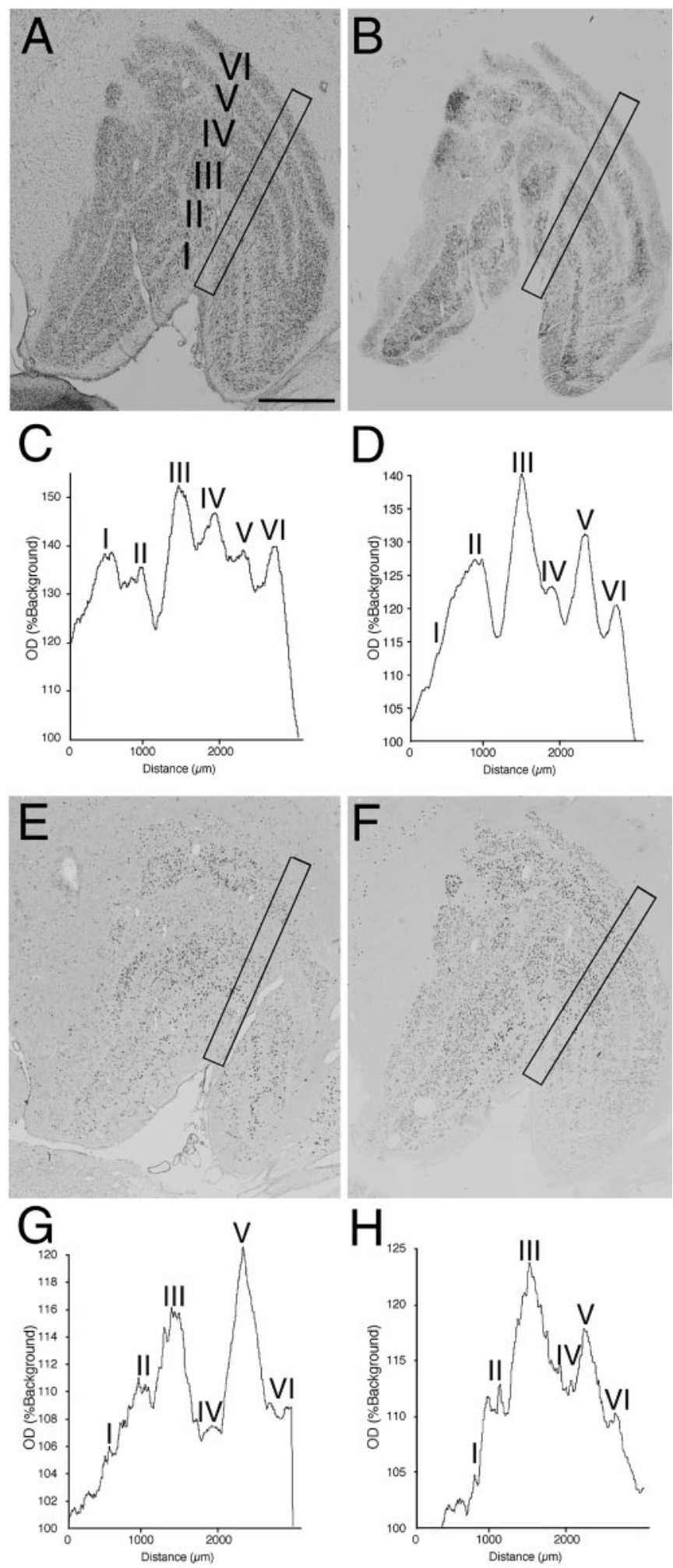

Figure 5. The effects of monocular deprivation in the LGN contralateral to the TTX-injected eye. This figure shows the results of the same monkey as in Figure 4. The hybridization signals for both GAP-43 and SCG10 mRNAs were lower in layers innervated by the TTX-injected eye (layers I, IV, and VI) than in layers innervated by a normal eye (layers II, III, and V). $A$, Nissl-stained section. $B$, Cytochrome oxidase-stained section. $C, O D$ (\%Background) from a $300-\mu \mathrm{m}$-wide column sampling all layers of Nissl-stained LGN $(A)$. D, OD(\%Background) from cytochrome oxidase-stained LGN $(B)$. E, Localization of GAP-43 mRNA. $F$, Localization of SCG10 mRNA. G, OD(\%Background) from the LGN hybridized for GAP-43 mRNA $(E)$. $H, O D(\%$ Background) from the LGN hybridized for SCG10 mRNA $(F)$. Scale bar, $1 \mathrm{~mm}$.

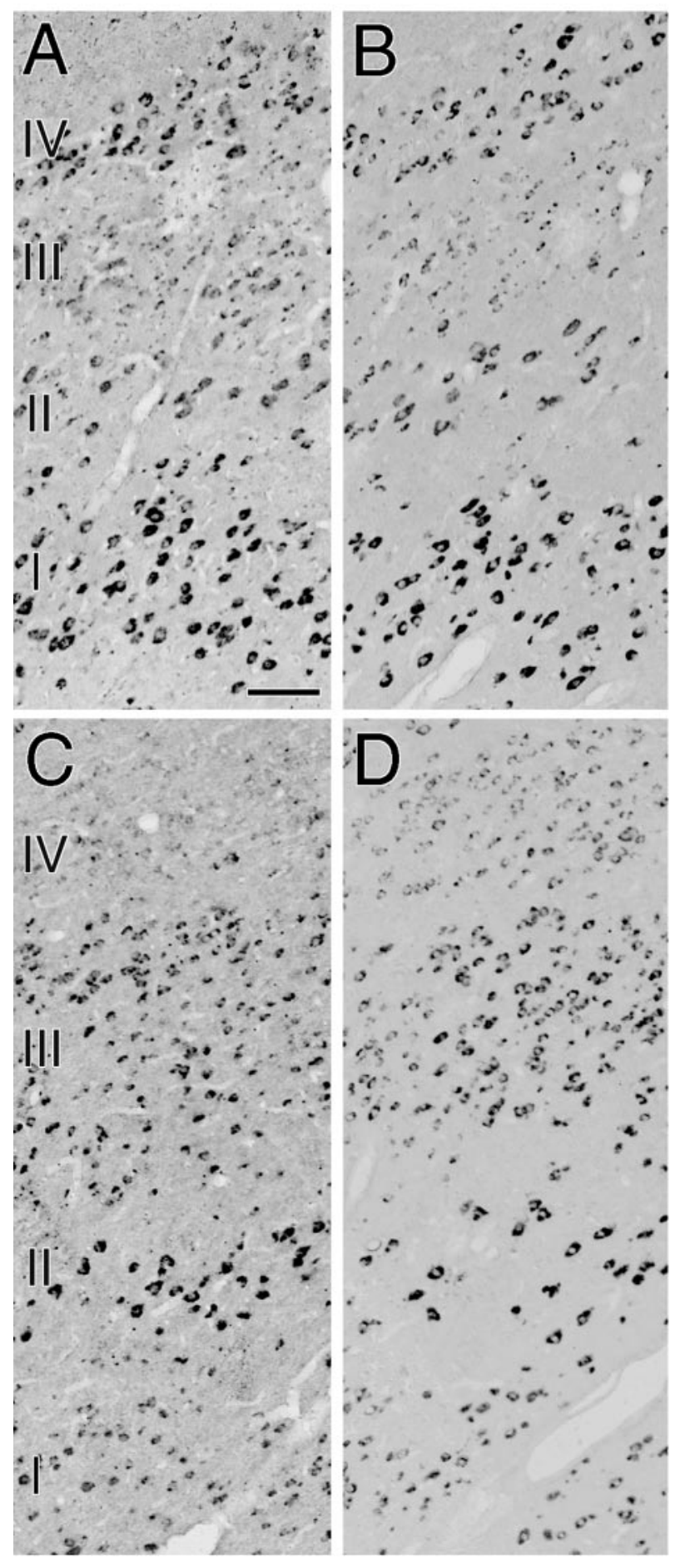

Figure 6. Higher-magnification photomicrographs showing downregulation of hybridization signals for GAP-43 mRNA $(A, C)$ and SCG10 mRNA $(B, D)$ after $10 \mathrm{~d}$ of monocular deprivation. $A, B$, Layers I-IV of the LGN ipsilateral to the TTX-injected eye. The photomicrographs were taken from the same section as in Figure 4. C, D, Layers I-IV of the LGN contralateral to the TTX-injected eye. The photomicrographs were taken from the same section as in Figure 5. Scale bar, $100 \mu \mathrm{m}$.

a critical period does not cause an alteration of GAP-43 mRNA levels in the cat primary visual area, although it results in a significant alteration of GAP-43 mRNA levels during early postnatal life (Mower and Rosen, 1993).

\section{Relationship to synaptic modifications in the visual system of the adult monkey}

During a critical period in the development of the visual system, the geniculocortical axons are supposed to compete with one an- 
A

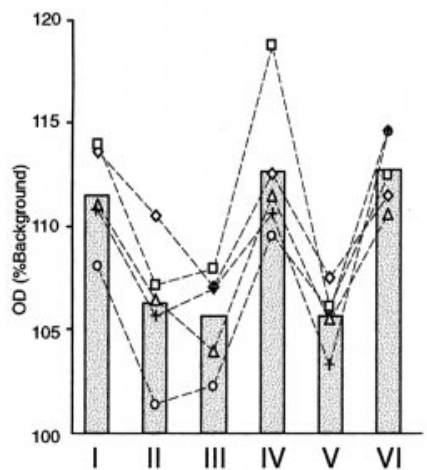

C

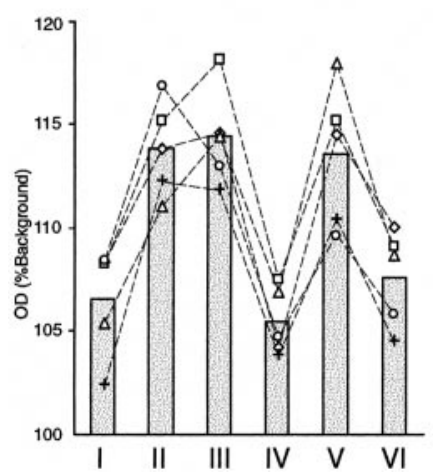

B

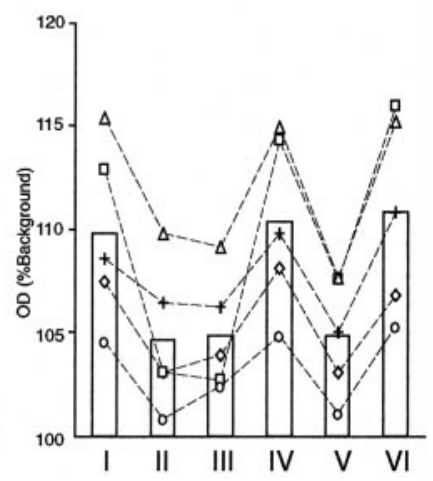

D

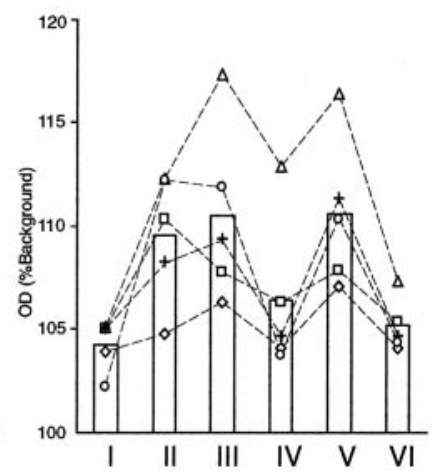

Figure 7. OD(\%Background) from each layer of the LGN hybridized for GAP-43 mRNA $(A, C)$ and SCG10 mRNA $(B, D) . A, B$, The LGN ipsilateral to the TTX-injected eye. $C, D$, The LGN contralateral to the TTX-injected eye. The hybridization signals for both GAP-43 and SCG10 mRNAs were reduced in the deprived layers (layers II, III, and V of the ipsilateral LGN and layers I, IV, and VI of the contralateral LGN) of all monocularly deprived monkeys regardless of the length of the deprivation period: $5 \mathrm{~d}$ (diamond and square), $10 \mathrm{~d}$ (triangle and circle), or $30 \mathrm{~d}$ (plus sign). $O D(\%$ Background) was measured from a $300-\mu \mathrm{m}$-wide column sampling each layer of the LGN. Bars indicate the average of five monkeys.

other for neurotrophins in layer IV of the primary visual area (Thoenen, 1995; Bonhoeffer, 1996; McAllister et al., 1999). Among neurotrophins, mRNA of brain-derived neurotrophic factor (BDNF) persists in layer IV of the adult primary visual area of cat, and the expression is downregulated after monocular deprivation for $2 \mathrm{~d}$ (Lein and Shatz, 2000). Moreover, TrkB, the putative receptor for $\mathrm{BDNF}$, is likely to exist in adult geniculocortical axons (Berardi and Maffei, 1999). Expression of both GAP-43 and SCG10 mRNAs is induced by BDNF (Fournier et al., 1997; Kobayashi et al., 1997; Imamura et al., 1999). Thus, the activitydependent expression of GAP-43 and SCG10 mRNAs in the adult LGN may be caused by the activity-dependent expression of BDNF in layer IV of the adult primary visual area.

Several lines of evidence relate the expression of mRNAs of the growth-associated proteins GAP-43 and SCG10 with structural synaptic reorganization in the adult nervous system (Van der Zee et al., 1989; Tetzlaff et al., 1991; Linda et al., 1992; Levin and Dunn-Meynell, 1993; Chong et al., 1994; Aigner et al., 1995; Holtmaat et al., 1995; Bendotti et al., 1997; McNeill et al., 1999). Therefore, the activity-dependent expression of GAP-43 and SCG10 mRNAs in the adult LGN suggests that the activitydependent plastic changes, such as proliferations or morphological alterations of synapses, occur in the geniculocortical axons of the adult monkey, even after geniculocortical axons lose the ability to extensively rearrange their terminals. Activity-dependent competition among geniculocortical synapses may account for some physiological expansion of ocular dominance columns serving the normal eye of the monocularly deprived monkey, as measured by single-unit recording [monkey no. 150 of LeVay et al. (1980)].
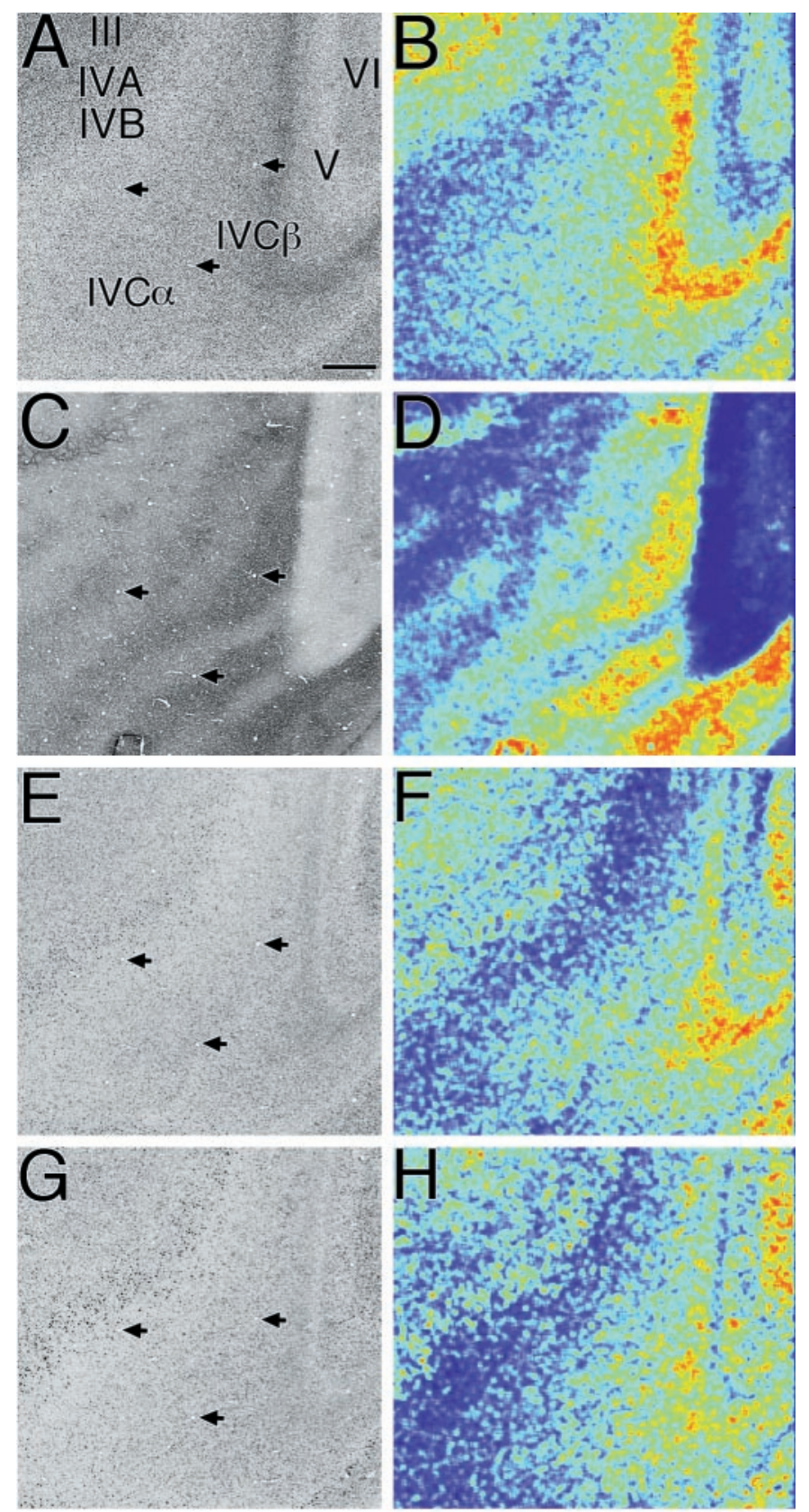

relative optical density

Min.

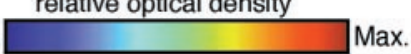

Figure 8. Surface parallel sections through the primary visual area (area 17 of Brodmann) of a monkey that has been monocularly deprived for $30 \mathrm{~d}$ $(A, C, E, G)$. The relative optical densities in each section were also shown in pseudocolor representation $(B, D, F, H) . A, B$, Nissl-stained section. $C, D$, Cytochrome oxidase-stained section. $E, F$, Localization of GAP-43 mRNA. $G, H$, Localization of SCG10 mRNA. The same blood vessels are indicated by arrows. No deprivation effect was observed for either GAP-43 or SCG10 mRNAs. Scale bar, $500 \mu \mathrm{m}$.

A previous study showed that MAP-2 immunostaining is reduced in ocular dominance columns of layer IVC serving the TTX-injected eye of monocularly deprived monkeys (Hendry and Bhandari, 1992). The result suggests that reorganization of microtubules occurs in the dendrites or dendritic spines of geniculocortical recipient neurons. Moreover, the $\alpha$-subunit of CAMKII is upregulated and the $\beta$-subunit of CAMKII is downregulated in the deprived ocular dominance column of layer IVC (Hendry and Kennedy, 1986; Benson et al., 1991; Tighilet et al., 1998a). Because CAMKII subserves an important part of protein kinase 
C-associated synaptic plasticity at postsynaptic density (Liu and Jones, 1996; Wu and Cline, 1998; Chakravarthy et al., 1999), the result further supports the idea that the geniculocortical synapses of the adult monkey still have some types of activity-dependent plasticity. The present results may provide presynaptic mechanisms of the plastic changes of the adult geniculocortical synapses.

A growing body of evidence indicates that the structural changes of subcortical structures contribute to reorganization of the somatosensory body map (for review, see Kaas et al., 1999). The present result suggests that subcortical structures of the adult brain have a role in plasticity not only in the somatosensory pathway but also in the visual pathway.

\section{A comparison with GABAergic system}

We showed that GAP-43 and SCG10 mRNAs were not expressed in GABAergic neurons in the LGN. In the perigeniculate nucleus, however, GABAergic neurons contained both GAP-43 and SCG10 mRNAs. GABAergic neurons in the LGN are interneurons (Fitzpatrick et al., 1984; Montero and Zempel, 1985, 1986), whereas GABAergic neurons in the perigeniculate nucleus have projections to relay neurons in the LGN (Cucchiaro et al., 1991; Uhlrich et al., 1991). Thus GAP-43 and SCG10 mRNAs are expressed in projection neurons of the monkey geniculate complex.

When monocular visual input is deprived in adult monkeys, GABA- and glutamate decarboxylase (GAD)-immunoreactive cell bodies and processes are decreased in layers of the LGN deprived of visual activity (Hendry, 1991). Deprivation periods of 3 weeks, however, are required to reduce the immunoreactivities of GABA and GAD (Hendry, 1991). The present results showed that both GAP-43 and SCG10 mRNAs were downregulated after monocular deprivation for periods of $5 \mathrm{~d}$. The relatively rapid downregulation of GAP-43 and SCG10 mRNAs is similar to that of GABA receptor subunits, which are downregulated after monocular deprivation for periods of $4 \mathrm{~d}$ (Huntsman et al., 1995; Hendry and Miller, 1996). $\mathrm{GABA}_{\mathrm{A}}$ receptor subunits (Hendry and Miller, 1996), as well as GAP-43 and SCG10 mRNAs, are expressed in relay neurons of the LGN. This suggests that the relatively rapid changes occur in the expression of molecules in relay neurons but that such changes are delayed in the inhibitory interneurons of the LGN.

In the perigeniculate nucleus, the expression of both GAP-43 and SCG10 mRNAs was retained even after monocular deprivation for each period. This is consistent with the studies of GABA and GAD immunoreactivities in the perigeniculate nucleus of monocularly deprived monkeys, which are identical to the immunoreactivities found in normal monkeys (Hendry, 1991). A previous study in cats reported that perigeniculate neurons typically are binocular (Xue et al., 1988). Thus, the present results indicate that monocular visual input may be sufficient for expressing both GAP-43 and SCG10 mRNAs as well as expressing GABA and GAD.

\section{REFERENCES}

Aigner L, Arber S, Kapfhammer JP, Laux T, Schneider C, Botteri F, Brenner H-R, Caroni P (1995) Overexpression of the neural growthassociated protein GAP-43 induces nerve sprouting in the adult nervous system of transgenic mice. Cell 83:269-278.

Akers RF, Routtenberg A (1985) Protein kinase C phosphorylates a $47 \mathrm{Mr}$ protein (F1) directly related to synaptic plasticity. Brain Res 334:147-151.

Alexander KA, Cimler BM, Meier KE, Storm DR (1987) Regulation of calmodulin binding to P-57. A neurospecific calmodulin binding protein. J Biol Chem 262:6108-6113.

Bendotti C, Baldessari S, Pende M, Southgate T, Guglielmetti F, Samanin R (1997) Relationship between GAP-43 expression in the dentate gyrus and synaptic reorganization of hippocampal mossy fibres in rats treated with kainic acid. Eur J Neurosci 9:93-101.

Benevento LA, Yoshida K (1981) The afferent and efferent organization of the lateral geniculo-prestriate pathways in the macaque monkey. J Comp Neurol 203:455-474.

Benowitz LI, Routtenberg A (1997) GAP-43: an intrinsic determinant of neuronal development and plasticity. Trends Neurosci 20:84-91.

Benowitz LI, Perrone-Bizzozero NI, Finklestein SP, Bird ED (1989) Localization of the growth-associated phosphoprotein GAP-43 (B-50, F1) in the human cerebral cortex. J Neurosci 9:990-995.

Benson DL, Isackson PJ, Gall CM, Jones EG (1991) Differential effects of monocular deprivation on glutamic acid decarboxylase and type II calcium-calmodulin-dependent protein kinase gene expression in the adult monkey visual cortex. J Neurosci 11:31-47.

Berardi N, Maffei L (1999) From visual experience to visual function: roles of neurotrophins. J Neurobiol 41:119-126.

Bonhoeffer T (1996) Neurotrophins and activity-dependent development of the neocortex. Curr Opin Neurobiol 6:119-126.

Bullier J, Kennedy H (1983) Projection of the lateral geniculate nucleus onto cortical area V2 in the macaque monkey. Exp Brain Res $53: 168-172$.

Chakravarthy B, Morley P, Whitfield J (1999) $\mathrm{Ca}^{+}{ }^{+}$-calmodulin and protein kinase Cs: a hypothetical synthesis of their conflicting convergences on shared substrate domains. Trends Neurosci 22:12-16.

Chong MS, Reynold ML, Irwin N, Coggeshall RE, Emson PC, Benowitz LI, Woolf CJ (1994) GAP-43 expression in primary sensory neurons following central axotomy. J Neurosci 14:4375-4385.

Cucchiaro JB, Uhlrich DJ, Sherman SM (1991) Electron-microscopic analysis of synaptic input from the perigeniculate nucleus to the A-laminae of the lateral geniculate nucleus in cats. J Comp Neurol 310:316-336.

Federoff H, Grabczyk E, Fishman MC (1988) Dual regulation of GAP-43 gene expression by nerve growth factor and glucocorticoids. J Biol Chem 263:19290-19295.

Fitzpatrick D, Penny GR, Schmechel DE (1984) Glutamic acid decarboxylase-immunoreactive neurons and terminals in the lateral geniculate nucleus of the cat. J Neurosci 4:1809-1829.

Fournier AE, Beer J, Arregui CO, Essagian C, Aguayo AJ, McKerracher L (1997) Brain-derived neurotrophic factor modulates GAP-43 but not T alpha1 expression in injured retinal ganglion cells of adult rats. J Neurosci Res 47:561-572.

Fries W (1981) The projection from the lateral geniculate nucleus to the prestriate cortex of the macaque monkey. Proc R Soc Lond B Biol Sci 213:73-86.

Fries W, Distel H (1983) Large layer VI neurons of monkey striate cortex (Meynert cells) project to the superior colliculus. Proc R Soc Lond B Biol Sci 219:53-59.

Garey LJ, Powell TP (1971) An experimental study of the termination of the lateral geniculo-cortical pathway in the cat and monkey. Proc R Soc Lond B Biol Sci 179:41-63.

Hannan AJ, Henke RC, Weinberger RP, Sentry JW, Jeffrey PL (1996) Differential induction and intracellular localization of SCG10 messenger RNA is associated with neuronal differentiation. Neuroscience 72:889-900.

Hendrickson AE, Wilson JR, Ogren MP (1978) The neuroanatomical organization of pathways between the dorsal lateral geniculate nucleus and visual cortex in Old World and New World primates. J Comp Neurol 182:123-136.

Hendrickson AE, Ogren MP, Vaughn JE, Barber RP, Wu JY (1983) Light and electron microscopic immunocytochemical localization of glutamic acid decarboxylase in monkey geniculate complex: evidence for gabaergic neurons and synapses. J Neurosci 3:1245-1262.

Hendry SH (1991) Delayed reduction in GABA and GAD immunoreactivity of neurons in the adult monkey dorsal lateral geniculate nucleus following monocular deprivation or enucleation. Exp Brain Res $86: 47-59$.

Hendry SH, Bhandari MA (1992) Neuronal organization and plasticity in adult monkey visual cortex: immunoreactivity for microtubule-associated protein 2. Vis Neurosci 9:445-459.

Hendry SH, Calkins DJ (1998) Neuronal chemistry and functional organization in the primate visual system. Trends Neurosci 21:344-349.

Hendry SH, Kennedy MB (1986) Immunoreactivity for a calmodulindependent protein kinase is selectively increased in macaque striate cortex after monocular deprivation. Proc Natl Acad Sci USA 83:1536-1541.

Hendry SH, Miller KL (1996) Selective expression and rapid regulation of $\mathrm{GABA}_{\mathrm{A}}$ receptor subunits in geniculocortical neurons of macaque dorsal lateral geniculate nucleus. Vis Neurosci 13:223-235.

Hendry SH, Yoshioka T (1994) A neurochemically distinct third channel in the macaque dorsal lateral geniculate nucleus. Science 264:575-577.

Higo N, Oishi T, Yamashita A, Matsuda K, Hayashi M (1998) Gene expression of growth-associated proteins, GAP-43 and SCG10, in the hippocampal formation of the macaque monkey: non-radioactive in situ hybridization study. Hippocampus 8:533-547.

Higo N, Oishi T, Yamashita A, Matsuda K, Hayashi M (1999a) Quantitative non-radioactive in situ hybridization study of GAP-43 and SCG10 mRNAs in the cerebral cortex of adult and infant macaque monkeys. Cereb Cortex 9:317-331.

Higo N, Oishi T, Yamashita A, Hayashi M (1999b) Activity-dependent regulation of GAP-43 and SCG10 mRNAs in the lateral geniculate nucleus of the macaque monkey. Jpn J Physiol 49:S144.

Higo N, Oishi T, Yamashita A, Matsuda K, Hayashi M (1999c) Expression of GAP-43 and SCG10 mRNAs in the lateral geniculate nucleus of the macaque monkey. Neurosci Res [Suppl] 23:S213.

Himi T, Okazaki T, Mori N (1994a) SCG10 mRNA localization in the hippocampus: comparison with other mRNAs encoding neuronal growth-associated proteins (nGAPs). Brain Res 655:177-185.

Himi T, Okazaki T, Wang TH, McNeill TH, Mori N (1994b) Differential localization of SCG10 and p19/stathmin messenger RNAs in adult rat 
brain indicates distinct roles for these growth-associated proteins. Neuroscience 60:907-926.

Holtmaat AJGD, Dijkhuizen PA, Oestreicher AB, Romijn HJ, Van der Lugt NMT, Berns A, Margolis FL, Gispen WH, Verhaagen J (1995) Directed expression of the growth-associated protein B-50/GAP-43 to olfactory neurons in transgenic mice results in changes in axon morphology and extraglomerular fiber growth. J Neurosci 15:7953-7965.

Hubel DH, Wiesel TN (1972) Laminar and columnar distribution of geniculo-cortical fibers in the macaque monkey. J Comp Neurol 146:421-450.

Huntsman MM, Leggio MG, Jones EG (1995) Expression patterns and deprivation effects on $\mathrm{GABA}_{\mathrm{A}}$ receptor subunit and GAD mRNAs in monkey lateral geniculate nucleus. J Comp Neurol 352:235-247.

Imamura K, Morii H, Yamada T, Kaub PA, Watanabe Y, Mori N (1999) Differential changes in messenger RNA expression of SCG10 family molecules in the LGN and visual cortex of kittens received direct cortical infusion of brain derived neurotrophic factor (BDNF). Soc Neurosc Abstr 25:1272.

Kaas JH, Florence SL, Jain N (1999) Subcortical contributions to massive cortical reorganizations. Neuron 22:657-660.

Kalyuzhny AE, Wessendorf MW (1998) Relationship of mu- and deltaopioid receptors to GABAergic neurons in the central nervous system, including antinociceptive brainstem circuits. J Comp Neurol 392:528-547.

Kapfhammer JP (1997) Axon sprouting in the spinal cord: growth promoting and growth inhibitory mechanisms. Anat Embryol (Berl) 196:417-426.

Kobayashi NR, Fan DP, Giehl KM, Bedard AM, Wiegand SJ, Tetzlaff W (1997) BDNF and NT-4/5 prevent atrophy of rat rubrospinal neurons after cervical axotomy, stimulate GAP-43 and T $\alpha 1$-tubulin mRNA expression, and promote axonal regeneration. J Neurosci 17:9583-9595.

Komatsu H (1998) Mechanisms of central color vision. Curr Opin Neurobiol 8:503-508.

Lein ES, Shatz CJ (2000) Rapid regulation of brain-derived neurotrophic factor mRNA within eye-specific circuits during ocular dominance column formation. J Neurosci 20:1470-1483.

LeVay S, Wiesel TN, Hubel DH (1980) The development of ocular dominance columns in normal and visually deprived monkeys. J Comp Neurol 191:1-51.

Levin BE, Dunn-Meynell A (1993) Regulation of growth-associated protein 43 (GAP-43) messenger RNA associated with plastic change in the adult rat barrel receptor complex. Mol Brain Res 18:59-70.

Linda H, Piehl F, Dagerlind A, Verge VMK, Arvidsson U, Chullheim S, Risling M, Ulfhake B, Hokfelt T (1992) Expression of GAP-43 mRNA in the adult mammalian spinal cord under normal conditions and after different types of lesions, with special reference to motoneurons. Exp Brain Res 941:284-295.

Liu XB, Jones EG (1996) Localization of alpha type II calcium calmodulin-dependent protein kinase at glutamatergic but not gammaaminobutyric acid (GABAergic) synapses in thalamus and cerebral cortex. Proc Natl Acad Sci USA 93:7332-7336.

Liu Y, Meiri KF, Cynader MS, Gu Q (1996) Nerve growth factor induced modification of presynaptic elements in adult visual cortex in vivo. Brain Res 732:36-42.

Lund JS, Boothe RG (1975) Interlaminar connections and pyramidal neuron organization in the visual cortex, area 17 , of the macaque monkey. J Comp Neurol 159:305-334.

Lysakowski A, Standage GP, Benevento LA (1988) An investigation of collateral projections of the dorsal lateral geniculate nucleus and other subcortical structures to cortical areas V1 and V4 in the macaque monkey: a double label retrograde tracer study. Exp Brain Res 69:651-661.

Martin PR, White AJ, Goodchild AK, Wilder HD, Sefton AE (1997) Evidence that blue-on cells are part of the third geniculocortical pathway in primates. Eur J Neurosci 9:1536-1541.

McAllister AK, Katz LC, Lo DC (1999) Neurotrophins and synaptic plasticity. Annu Rev Neurosci 22:295-318.

McNeill TH, Cheng H-W, Rafols JA, Mori N (1992) Neuroplasticity and Parkinson's disease. In: Progress in Parkinson's disease research (Hefti F, Weiner WJ, eds), pp 299-323. New York: Plenum.

McNeill TH, Mori N, Cheng HW (1999) Differential regulation of the growth-associated proteins, GAP-43 and SCG-10, in response to unilateral cortical ablation in adult rats. Neuroscience 90:1349-1360.

Meiri KF, Pfenninger KH, Willard MB (1986) Growth-associated protein, GAP-43, a polypeptide that is induced when neurons extend axons, is a component of growth cones and corresponds to pp46, a major polypeptide of a subcellular fraction enriched in growth cones. Proc Natl Acad Sci USA 83:3537-3541.

Meiri KF, Willard M, Johnson MI (1988) Distribution and phosphorylation of the growth-associated protein GAP-43 in regenerating sympathetic neurons in culture. J Neurosci 8:2571-2581.

Montero VM, Zempel J (1985) Evidence for two types of GABAcontaining interneurons in the A-laminae of the cat lateral geniculate nucleus: a double-label HRP and GABA- immunocytochemical study. Exp Brain Res 60:603-609.

Montero VM, Zempel J (1986) The proportion and size of GABAimmunoreactive neurons in the magnocellular and parvocellular layers of the lateral geniculate nucleus of the rhesus monkey. Exp Brain Res $62: 215-223$.
Mower GD, Rosen KM (1993) Developmental and environmental changes in GAP-43 gene expression in cat visual cortex. Mol Brain Res 20:254-258.

Nelson RB, Routtenberg A (1985) Characterization of protein F1 (47 $\mathrm{kDa}, 4.5 \mathrm{pI})$ : a kinase C substrate directly related to neural plasticity. Exp Neurol 89:213-224.

Neve RL, Finch EA, Bird ED, Benowitz LI (1988) Growth-associated protein GAP-43 is expressed selectively in associative regions of the adult human brain. Proc Natl Acad Sci USA 85:3638-3642.

Nishizawa K (1994) NGF-induced stabilization of GAP-43 mRNA is mediated by both $3^{\prime}$ untranslated region and a segment encoding the carboxy-terminus peptide. Biochem Biophys Res Commun 200:789-796.

Oishi T, Higo N, Umino Y, Matsuda K, Hayashi M (1998) Development of GAP-43 mRNA in the macaque cerebral cortex. Dev Brain Res 109:87-97.

Perrone-Bizzozero NI, Cansino VV, Kohn DT (1993) Posttranscriptional regulation of GAP-43 gene expression in PC12 cells through protein kinase C-dependent stabilization of the mRNA. J Cell Biol 120:1263-1270.

Peters A (1994) The organization of the primary visual cortex in the macaque. In: Cerebral cortex, Vol 10, Primary visual cortex in primates (Peters A, Rockland KS, eds), pp 1-35. New York: Plenum.

Reid RC, Alonso J-M, Hendry SHC (1997) S-cone input is relayed to visual cortex from two koniocellular layers of macaque LGN. Soc Neurosci Abstr 23:13.

Riederer BM, Pellier V, Antonsson B, Di Paolo G, Stimpson SA, Lutjens R, Catsicas S, Grenningloh G (1997) Regulation of microtubule dynamics by neuronal growth-associated protein SCG10. Proc Natl Acad Sci USA $94: 741-745$.

Sipp S, Zeki S (1989) The organization of connections between area V5 and V1 in macaque monkey visual cortex. Eur J Neurosci 1:309-332.

Skene JHP, Jacobson RD, Snipes GJ, McGuire CB, Norden JJ, Freeman JA (1986) A protein induced during nerve growth (GAP-43) is a major component of growth-cone membranes. Science 233:783-786.

Stein R, Mori N, Matthews K, Lo L-C, Anderson D (1988a) The NGFinducible SCG10 mRNA encodes a novel membrane-bound protein present in growth cones and abundant in developing neurons. Neuron $1: 463-476$.

Stein R, Orit S, Anderson DJ (1988b) The induction of a neural-specific gene, SCG10, by nerve growth factor in PC12 cells is transcriptional, protein synthesis dependent, and glucocorticoid inhibitable. Dev Biol 127:316-325.

Strittmatter SM, Valenzuela D, Kennedy TE, Neer EJ, Fishman MC (1990) Go is a major growth cone protein subject to regulation by GAP-43. Nature 344:836-839.

Sugiura Y, Mori N (1995) SCG10 expresses growth-associated manner in developing rat brain, but shows a different pattern to $19 /$ stathmin or GAP-43. Dev Brain Res 90:73-91.

Tanigawa H, Fujita I, Kato M, Ojima H (1998) Distribution, morphology, and gamma-aminobutyric acid immunoreactivity of horizontally projecting neurons in the macaque inferior temporal cortex. J Comp Neurol 401:129-143.

Tetzlaff W, Alexander SW, Miller FD, Bisby MA (1991) Response of facial and rubrospinal neurons to axotomy: changes in mRNA expression for cytoskeletal proteins and GAP-43. J Neurosci 11:2528-2544.

Thoenen H (1995) Neurotrophins and neuronal plasticity. Science 270:593-598.

Tigges J, Tigges M, Anschel S, Cross NA, Letbetter WD, McBride RL (1981) Areal and laminar distribution of neurons interconnecting the central visual cortical areas 17, 18, 19, and MT in squirrel monkey (Saimiri). J Comp Neurol 202:539-560.

Tighilet B, Hashikawa T, Jones EG (1998a) Cell- and lamina-specific expression and activity-dependent regulation of type II calcium/ calmodulin-dependent protein kinase isoforms in monkey visual cortex. J Neurosci 18:2129-2146.

Tighilet B, Huntsman MM, Hashikawa T, Murray KD, Isackson PJ, Jones EG (1998b) Cell-specific expression of type II calcium/calmodulindependent protein kinase isoforms and glutamate receptors in normal and visually deprived lateral geniculate nucleus of monkeys. J Comp Neurol 390:278-296.

Uhlrich DJ, Cucchiaro JB, Humphrey AL, Sherman SM (1991) Morphology and axonal projection patterns of individual neurons in the cat perigeniculate nucleus. J Neurophysiol 65:1528-1541.

Van der Zee CEEM, Nielander HB, Vos JP, Lopes da Silva S, Verhaagen J, Oestreicher AB, Schrama LH, Schotman P, Gispen WH (1989) Expression of growth-associated protein B-50 (GAP43) in dorsal root ganglia and sciatic nerve during regenerative sprouting. $\mathrm{J}$ Neurosci 9:3505-3512.

Wilson ME, Cragg BG (1967) Projections from the lateral geniculate nucleus in the cat and monkey. J Anat 101:677-692.

Wu GY, Cline HT (1998) Stabilization of dendritic arbor structure in vivo by CaMKII. Science 279:222-226.

Xue JT, Carney T, Ramoa AS, Freeman RD (1988) Binocular interaction in the perigeniculate nucleus of the cat. Exp Brain Res 69:497-508.

Yukie M, Iwai E (1981) Direct projection from the dorsal lateral geniculate nucleus to the prestriate cortex in macaque monkeys. J Comp Neurol 201:81-97. 